\title{
The Land Rent Theory Evolution in Sustainable Development Paradigm
}

\author{
Olesya Ivanenko ${ }^{1, *}$ \\ ${ }^{1}$ Financial University under the Government of the Russian Federation, Omsk Branch 64400143 \\ Maslennikova st., Omsk, Russia
}

\begin{abstract}
The problem of land rent is directly related to the achievement of the limit of land involvement in agricultural production. In turn, the paradigm of sustainable development includes the issues of the constant growth of the food security of the people of the Earth, the fight against hunger, etc. The theoretical and methodological foundations of land rent are considered in the paradigm of sustainable development, in relation to the evolution of the concepts of leading scientific schools. The nature of land rent is described, its main types and sources of genesis are revealed. From the point of view of the institutional approach, land rent is considered as an institutional relation. The category of the land rent institution has been clarified. The role of land rent in ensuring sustainable development in the understanding of various schools of economics is shown; conclusions are drawn that make it possible to distinguish the features of basic approaches to determining land rent from the perspective of key sustainable development issues studied by schools of economics. It is concluded that it is necessary to use an integrated approach to the study of the category of land rent as a combination of environmental, cognitive, economic and institutional relations.
\end{abstract}

\section{Introduction}

Currently, studies of sustainable development opportunities inevitably affect the problem of limited land resources and the difficulty of increasing food production. In this regard, it is important to analyze the approaches to the study of the main aspect of the involvement of land resources in the economic turnover - the land rent.

At every stage in the development of economics science, researchers are constantly affecting rental issues, seeking to explain the nature of this phenomenon. Thus, the first mention of land rent can be found already in the writings of the Greek (Aristotle, IV. BC) and Roman (Caton, III - II. BC, Varro, II - I century BC) authors. Separate questions of the theory of land rent were worked out by physiocrats. Modern approaches to the study of the theory of nature, in particular land rent, are presented by the classical, neoclassical and institutional paradigm, closely observing sustainable development.

But despite all attempts to explain this definition, the topic of land rent, sources of its formation, distribution and withdrawal remains modern and relevant, which, in our opinion,

\footnotetext{
*Corresponding author: olesya ivanenko@bk.ru
} 
is due to the lack of a completed theoretical concept, insufficient systematization of approaches to its analysis within the declared schools of economics.

\section{Materials and Methods}

The conceptual foundations of the theory of land rent were made by representatives of the classical school of political economy: W. Petty, A. Smith, D. Ricardo, I. Thunen, and others. Therefore, for the first time, W. Petty analyzed land rent based on the theory of labor value. In his definition, rent is a part of value and is a product of surplus labor appropriated by the owner of the land [1]. The source of rent formation, based on this, is the labor of hired workers in the conditions of certain property relations, and its emergence is associated with the development of private land ownership.

Justifying the existence of land rent, A. Smith indicates that the factors of production, including natural resources, must be paid. However, A. Smith theory is characterized by a dual approach in relation to this category. Based on the theory of labor value, the rent is considered as the unpaid labor of an agricultural worker. But at the same time, the land rent is presented as "the product of nature, which remains after compensation of all that can be considered a work of man" $[2,3]$. Thus, rent in Smith's concept is the result of a monopoly on agricultural production.

Developing the theory of land rent, D. Ricardo in his interpretation of the nature of rent, overcame A. Smith's dualism. He showed that land rent is determined by labor under the conditions of a particular type of property. Moreover, D. Ricardo substantiated that before the emergence of individual ownership of land, rent of land did not exist, since the land was a gift of nature. "No one will pay for the use of land," he wrote, "since there is a lot of land that has not yet become property, which therefore anyone who wants to work on it can possess" [4]. Ricardo, determining the derivative nature of the demand for land, makes an important conclusion that the price of grains is high not because the price of land is high, but on the contrary, the price of land is high because the price of grain produced on them is high. Developing the theory of land rent, D. Ricardo essentially determines rent-forming factors: the difference in fertility and the different remoteness of land from sales markets for products. The limiting analysis he proposed became the methodological basis for determining the amount of rent for subsequent researchers.

A significant contribution to the further study of the theory of rent was made by $\mathrm{K}$. Marx. In his writings, dwelling on the concept, genesis and mechanism of land rent formation, he noted that "whatever the specific form of rent is, all its types are in general the fact that rent appropriation is an economic form in which land ownership is realized, and that land rent, in turn, implies land ownership ..." [4].

Summarizing the development of the classical school, K. Marx made significant contribution to the theory of rent. Therefore, he clearly determined that in addition to the differential, there is an absolute rent. In the formation of the theory of absolute rent of $\mathrm{K}$. Marx, the study of I. Rodbertus about the possibility of the emergence of a larger surplus product in agriculture than in industry due to the unequal capital structure in these sectors was of significant importance [5].

Developing the theory of rent, K. Marx singled out monopoly rent, withdrawing it from the monopoly price, which "... is determined only by the desire to buy and buyers' solvency, regardless of price, determined both by the total price of production and the cost of products" [4].

So, analyzing K. Marx's theory of land rent, one can make an input that it was determined not only the cause (land monopoly), but also the conditions (difference in economic and environmental conditions) and sources (unpaid surplus labor of hired workers) for the formation of land rent . 
Summing up, we note that the definition of land rent by representatives of classical and Marxist schools is defined as part of the system of economic relations between land users and land owners. Rent is a form of surplus value, part of the surplus product. Its genesis is associated with the emergence of private ownership of land, and the source of genesis is labor in agriculture. At the same time, with all the obvious achievements, the representatives of this approach paid little attention to the initial formation of the size of land rent, did not take into account that land is transferred for leasing, and its value is formed by participants in land relations in the exchange sphere and only after that the amount of rent is determined.

In contrast to the classical theory, representatives of the neoclassical direction are repelled not from labor value, but from the concept of rarity and utility, focusing on the analysis of the market mechanism of rent formation and distribution. The stage of resource circulation is coming to the fore: the possibility of the market circulation of land depending on market conditions, market structure and the connection between the amount of rent and the dynamics of supply and demand is investigated.

In turn, land rent is discussed as a special case of the phenomenon of comman rent. Alfred Marshall emphasizes that "... even land rent is not seen as an isolated category, but as the main variety of a number of phenomena, it, of course, has its specific features of primary and practical importance" [7]. Thus, the theory of rent acquires much greater significance than in the classical approach. If before classics, the rent was only land rent, now in all models of rational behavior of economic entities it is assumed that these entities can receive some kind of rent, as "income from the use of resources minus the part that corresponds to income from their best alternative applications" [13]. D. Lindsay and E.J. Dollan named such a rent as a net economic rent [6].

However, rental income in neoclassical interpretation is primarily related to income from land tenure and land use. However, as a source of rent, the land, and not the labor was considered. The economic content of the nature of land rent is justified by the presence of a distinction between the primeval (inseparable) properties of land plots on the one hand, and artificial properties on the other, to which the earth is obliged to human labor activity. Based on the fact of the constant character of the land supply, the category of demand is proposed by neoclassicists as the only factor determining the level of rent. Thus, it determines the importance of the very factor of production (in particular, land) for satisfying the economic needs of a person. The value of the factor, as well as the probability of receiving a rent from its use, is determined by its subjective consumer characteristics. This fact is particularly emphasized in the definition of the category of land rent.

Another feature of the research in this area is the allocation of time periods for analysis ("short" and "long" one), and the allocation in this connection of quasi-rent as a temporary surplus of income resulting from the improvement of agricultural technology and the intensive use of land [7].

Researches of the representatives of the neoclassical school had practical significance. Therefore, when considering land rent A. Marshall raises the problem of taxation: what part of the income to consider rent and how to tax it. For this purpose, the annual value of land is divided into three parts: the initial (inalienable) value, the common value (public value) and private value. The first two parts, according to the terminology of A. Marshall, are the annual social value of land or "real rent" [7], which is the permissible limit of rent exemption from the land user. At the same time, he noted, it is impractical to extend the exemption to the part that is called "private value" and it is unacceptable to affect the withdrawal of a part of the proceeds, reimbursing variable production costs.

Therefore, the theory of rent became the basis for the idea of withdrawing rental income through taxation. L. Walras adhered to the most radical idea of nationalization of the land, justifying his thought on the one hand by the lack of efficiency of land use by private 
landowners. On the other hand, the receipt of land rent by the state, from the point of view of L. Walras, would allow replacing all taxes. To this end, the state should begin to buy land [14].

The original idea of another extreme concept within the neoclassical school was the identification of land with capital. Therefore, J.B. Clark, considering land rent as a percentage of capital, puts forward the idea that there is no point in introducing land tax if the land is the same assets [8].

Representatives of the modern neoclassical direction D.L. Rubinfeld and R.S. Pindyke as a source of economic rent determined positive accounting profits resulting from the possession of limited resources, which can be not only land, but also other natural resources, entrepreneurial abilities or creative abilities of a person [9].

Summing up, it can be noted that within the framework of the neoclassical direction, an analysis was made of the market mechanism for the formation and distribution of rent; an assumption is made about the probability of its genesis not only from the earth, but also from other factors of production. From their point of view, this is due to price inelasticity of the supply of any kind of resources, including not only land, but also fixed assets, as well as labor. At the same time, representatives of this approach stressed that the emergence of rent is associated with the exclusivity of rights to the resource. But at the same time, they did not take into account the fact of the specificity of resources and the specification of property rights.

\section{Results and Discussion}

The generality of the presented theories is that land rent is considered as part of economic relations transformed into rental relations. However, in turn, rental relations are an integral part of economic activity, which is a single system of economic and institutional relations. Thus, the institutional aspect of the study of land rent, as we see it, is inevitable due to both the explicit and implicit presence of institutions at the stages of genesis, use and distribution of rent.

Institutional economics focuses on the non-ideality of the market due to transaction costs. The search for solutions is carried out taking into account opportunistic behavior, imperfect information, limited rationality. Within this approach, rent is regarded as an institution of society. The following prerequisites are put forward as initial methodological postulates for the analysis of land rent:

- full mobility of the factor of production (land) in the economic sense;

- only the results of the work of market forces, that is, the amount of rent paid and received, fall within the scope of the study;

- the question of the source of rent, as a product of the land, is often ignored;

- study of the problems of rent assessment from the point of view of the theory of property rights to the rental factor focus on clarifying the boundaries (specification) of property rights;

- clarification of the role of the state in the distribution of rental income is increasing.

The research tool of the problem of land rent definition is the research of R. Coase. His central idea is that economic resources with free exchange move to the field of their most beneficial use. Rent is defined as "... the difference between what a production factor brings in a given activity and what it can bring with its best alternative use" [10]. Therefore, R. Coase concludes that it would be reasonable if the state, in its activities, was guided by the principle of minimizing transaction costs and sought to endow with the rights of "effective owners," that is, those economic entities that, with zero transaction costs, would become their ultimate holders [11]. 
Another important point in the research of the institutional direction is the assumption of the dispersal of rent, suggesting that, due to the lack of exclusive rights to use, the competition of economic entities reduces the rental value of public property to zero [11].

The formal and informal rules (economic, political, social, legal, psychological) specifications of property rights, determining the value of land rent begin to play a special role. From our point of view, this is explained by the presence of an immanent connection between the economic content of land rent and its institutional form. Thus, the institutional approach allows us to consider land rent as a single system of economic and institutional relations. The institutional nature of rent is expressed in the specification of ownership rights to rental income, and economic - in the nature of its economic use [12].

Based on the analysis of the institutional meaning of land rent, its institute can be defined as a complex category that combines a system of such components as formal and informal norms and rules, as well as internal and external coercive mechanisms that streamline the interaction of landowners, landowners and the state devoted to withdrawal, distribution and use of rental income.

As a result of the study of various concepts and views on the theory of land rent, it can be concluded that in the works of the classical and Marxist school land rent is considered as an additional income of land users arising from the production of agricultural products. In the neoclassical interpretation, land rent is considered as the price of a resource arising from the use of land. The commonality of these theoretical approaches lies in the interpretation of land rent as part of economic relations. At the same time, the growing interest to the institutional paradigm of research has necessitated the consideration of land rent as part of institutional relations that take into account the legal aspects of economic activity. However, in all the approached observed, land rent is a complex, multidimensional category.

Therefore, based on the results of the study, we can conclude about the need to use an integrated approach to the study of the category of land rent as a set of economic and institutional relations. This approach will allow us to explain the essence of rent, not only as the value or price of an economic resource, but also as a result of the impact of economic institutions and the institutional environment on the decision-makers in rental relations.

\section{Conclusion}

Summing all spoken above, we concluded, that market issues of land use, including land rent, are essential for understanding sustainable development paths. Accordingly, the definition of land rent, issues of its formation, withdrawal, distribution and use must be studied from the standpoint of classical, neoclassical and institutional schools, depending on the level of the problem under consideration. Directly within the framework of the relationship of land rent relations as a system of economic and institutional relations, a fullfledged and multilateral analysis of these relationships is likely.

\section{References}

1. W. Petty, Treatise on taxes and fees (Willey and Sons, London, 1963)

2. A. Smith, Study on the nature and causes of the wealth of nations (Logan, Suffolk Print, 1978)

3. D. Ricardo, The Beginning of Political Economy and Taxation (Poddings Pub., London, 1988)

4. K. Marx, Capital (KMSC Foundation, Dresden, 1971) 
5. I. Rodbertus, The 3rd Social Letter to fon Kirsman (Goldstein, Berlin, 1851)

6. E.J. Dollan, D. Linsday, Microeconomics (Sun Co, Los Angeles, 2003)

7. A. Marshall, Principles of Economic Science (Willey and Sons, London, 1992)

8. J. B. Clark, The distribution of wealth (Penguin, New York, 2000)

9. R. S. Pindyk, D.L. Rubinfield, Microeconomics (Willey and Sons, London, 1999)

10. R. Coase, Firm, Market and Law (Penguin, New York, 2000)

11. V.S. Avtonomov, Land Rent (MSU, Moscow, 2004)

12. L.V. Grishaeva, O.B. Ivanenko, Institutional mechanism for the implementation of land rent in agriculture (Sphere, Omsk, 2010)

13. J. M. Buchanan, R. D. Tollison, G. Tullock, Rent-Seeking and Profit Seeking. Toward a Theory of the Rent-Seeking Society (Texas A\&M University Press, College Station, 1980)

14. L. Walras, Etudies d'economie social: Theorie de la repartition de la richesse (Giant Pub., Lausanne-Paris, 1896) 